\title{
YIELD GAINS OF COFFEE PLANTS FROM PHOSPHORUS FERTILIZATION MAY NOT BE GENERALIZED FOR HIGH DENSITY PLANTING(1)
}

\author{
Samuel Vasconcelos Valadares ${ }^{(2)}$, Júlio César Lima Neves ${ }^{(3)}$, Roberto Ferreira Novais ${ }^{(4)}$, \\ Gustavo Nogueira Guedes Pereira Rosa ${ }^{(5)}$, Hermínia Emília Prieto Martinez ${ }^{(6)}$ \& Víctor \\ Hugo Alvarez V. ${ }^{(3)}$
}

\begin{abstract}
SUMMARY
Inconclusive responses of the adult coffee plant to phosphorus fertilization have been reported in the literature, especially when dealing with application of this nutrient in high density planting systems. Thus, this study was carried out for the purpose of assessing the response of adult coffee plants at high planting density in full production (in regard to yield and their biennial cycle/stability) to the addition of different sources and application rates of $P$ in the Zona da Mata region of Minas Gerais, Brazil. The experiment with coffee plants of the Catucaí Amarelo 6/30 variety was carried out over four growing seasons. Treatments were arranged in a full factorial design $[(4 \times 3)+1]$ consisting of four $P$ sources (monoammonium phosphate, simple superphosphate, natural reactive rock phosphate from Algeria (Djebel-Onk), and FH 550®), three $P$ rates $\left(100,200\right.$, and $400 \mathrm{~kg} \mathrm{ha}^{-1}$ year-1 of $\mathrm{P}_{2} \mathrm{O}_{5}$ ), and an additional treatment without application of the nutrient $\left(0 \mathrm{~kg} \mathrm{ha}^{-1} \mathrm{year}^{-1}\right)$. A randomized block experimental design was used with three replicates. The four seasons were evaluated as subplots in a split plot experiment. The $P$ contents in soil and leaves increased with increased rates of $P$ application. However, there was no effect from $P$ application on the yield and its biennial cycle/stability regardless of the source used over the four seasons assessed.
\end{abstract}

Index terms: Coffea arabica, mineral nutrition, biennial cycle/stability.

(1) Part of the Master's Thesis of the first author presented at the Federal University of Viçosa (Universidade Federal de Viçosa) - UFV. Received for publication on December 13, 2012 and approved on March 5, 2014.

${ }^{(2)}$ Doctoral student in Soil Science and Plant Nutrition, Soil Department, UFV. Av. P.H. Rolfs, s/n. CEP 36570-900 Viçosa (MG), Brazil. E-mail: samuel.valadares@ufv.br

(3) Professor, Soil Department, UFV. E-mail: julio_n2003@yahoo.com.br, vhav@ufv.br

(4) Pesquisador Visitante Nacional Sênior. UFV, Campus Rio Paranaíba. Bolsista da CAPES. E-mail: rfnovais@ufv.br

(5) Master of Science, Fertilizantes Heringer S/A. BR 262, km 39,4, Ponte da Aldeia. CEP 36900-000 Manhuaçu (MG), Brazil. Email: gustavongpr@hotmail.com

(6) Professor, Plant Science Department, UFV. E-mail: hermínia@ufv.br 


\title{
RESUMO: OS GANHOS DE PRODUTIVIDADE DE CAFEEIROS ADULTOS ADENSADOS, COM A FERTILIZAÇÃO FOSFATADA, NÃO PODEM SER GENERALIZADOS
}

\begin{abstract}
Respostas não conclusivas do cafeeiro adulto à fertilização com fósforo têm sido reportadas na literatura, de modo particular quando se trata da aplicação desse nutriente em sistemas adensados de plantio. Assim, este trabalho foi realizado com o objetivo de avaliar a resposta de cafeeiros adensados adultos, em franca produção, quanto à produtividade e bienalidade, $\grave{a}$ adição de diferentes fontes e doses de $P$, na região da Zona da Mata de Minas Gerais. O experimento, com cafeeiros da variedade Catucaí Amarelo 6/30, foi conduzido durante quatro safras. A matriz experimental utilizada foi o fatorial completo [( $4 \times 3)+1]$, composto por quatro fontes (fosfato monoamônico, superfosfato simples, fosfato natural reativo da Argélia (Djebel-Onk) e FH 550 $\left.{ }^{\circledR}\right)$, três doses de $\mathrm{P}\left(100,200\right.$, e $400 \mathrm{~kg} \mathrm{ha^{-1 }}$ ano ${ }^{-1}$ de $\left.\mathrm{P}_{2} \mathrm{O}_{5}\right)$ e um tratamento adicional, correspondente à dose de $0 \mathrm{~kg} \mathrm{ha} a^{-1}$ ano $^{-1}$ de $\mathrm{P}_{2} \mathrm{O}_{5}$. O delineamento utilizado foi em blocos casualizados, com três repetições. As quatro safras constituíram faixas no tempo. Houve aumento dos teores de P no solo e nas folhas do cafeeiro com o aumento das doses aplicadas. Apesar disso, não houve efeito da adição de P sobre a produtividade e a bienalidade da produção das plantas, independentemente da fonte utilizada ao longo das quatro safras avaliadas.
\end{abstract}

Termos de indexação: Coffea arabica, nutrição mineral, bienalidade.

\section{INTRODUCTION}

The coffee plant (Coffea arabica) is among the most highly studied perennial crops in Brazil, which is the largest worldwide exporter of the product, with particular importance for the state of Minas Gerais, where $50 \%$ of Brazilian coffee is produced (CONAB, 2010). Among the traditional coffee-producing mesoregions, the Zona da Mata is responsible for around $21 \%$ of production in the State of Minas Gerais (Emater, 2009). This region is characterized by highly rolling topography and, predominantly, family farms, in contrast with the newer coffee-growing regions in the State, such as the Cerrado (Brazilian tropical savanna) regions, where, in general, the mechanization of production processes and large size of agricultural areas facilitate large scale systems and ensure greater competitiveness in this sector. Even so, the relevance of coffee growing in these more traditional regions is strong, especially for small family farm properties (INAES, 2010).

Various techniques assist farmers in competing in the market. Among them, the high density planting system, characterized by plant population densities from 5,000 to 10,000 plants ha ${ }^{-1}$, stands out as an alternative for improving the viability of coffee growing (Nacif, 1997), especially on highly rolling land and small properties. This system, when adequately managed, allows intensification in the use of agricultural areas, with greater yields and better efficiency in the use of labor and inputs.

Even without high density planting, the responses of the adult coffee plant to fertilization are highly variable (Prezotti \& Rocha, 2004). For this reason, studies have been developed to assess the response of high density coffee planting to fertilization in some producing regions (Pavan et al., 1994; Prezotti \& Rocha, 2004; Figueiredo et al., 2006; Bragança et al., 2009).
The coffee plant is considered not very responsive to fertilization with $\mathrm{P}$ during the production period. Nevertheless, studies have shown expressive responses to the addition of this nutrient in some producing regions (Gallo et al., 1999; Reis et al., 2011). Even so, it might not be possible to extrapolate the conclusions and/or recommendations obtained to other growing regions, given the diversity of environments and management conditions of the crop. In addition, studies usually do not consider the effect on the biennial production cycle of the coffee plant.

Although it is an important coffee producing region, there is a lack of information for the Zona da Mata of Minas Gerais in regard to phosphate fertilization of coffee plants in high density planting. Thus, the aim of this study was to assess the response of coffee, in high density planting in the production phase, to the addition of different sources and rates of $\mathrm{P}$ application, particularly in regard to yield and the biennial production cycle in this region.

\section{MATERIAL AND METHODS}

The experiment was carried out in the Centro de Pesquisas Cafeeiras Eloy Carlos Heringer (CEPEC) [Eloy Carlos Heringer Coffee Research Center], located in the municipality of Martins Soares, MG, Brazil (latitude $20^{\circ} 14$ ' $45^{\prime \prime} \mathrm{S}$ and longitude $41^{\circ} 50^{\prime} 47^{\prime \prime} \mathrm{E}$ ) at $740 \mathrm{~m}$ altitude, in an area of Latossolo VermelhoAmarelo distrófico (Embrapa, 2006) soil [Oxisol]. The chemical characteristics of the soil are shown in table 1 . The variety used was Catucaí Amarelo 6/30, at a spacing of $2.5 \times 0.6$ (population density of 6,666 plants $\mathrm{ha}^{-1}$ ). Climate in the region, according to the Köppen classification, is mesothermal, with rainy summers (Cwa). 
Table 1. Chemical characteristics of the soil used in the experiment $(0-20 \mathrm{~cm})^{(1)}$

\begin{tabular}{|c|c|c|c|c|c|c|c|c|}
\hline $\mathrm{pH}\left(\mathrm{H}_{2} \mathrm{O}\right)$ & $\mathbf{P}$ & $\mathbf{K}$ & $\mathrm{Ca}^{2+}$ & $\mathrm{Mg}^{2+}$ & $\mathrm{Al}^{3+}$ & $\mathrm{H}+\mathrm{Al}$ & OM & P-rem \\
\hline & 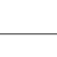 & $\mathrm{n}^{-3}$ & 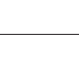 & $\mathrm{c}$ & & & dag $\mathrm{kg}^{-1}$ & $\mathrm{mg} \mathrm{L}^{-1}$ \\
\hline 5.21 & 6.4 & 139.8 & 1.28 & 0.28 & 0.24 & 4.60 & 1.98 & 25.7 \\
\hline
\end{tabular}

(1) Mean values obtained in the control treatment in 2008 and 2009. $\mathrm{P}$ and K: extractor Mehlich-1; Ca, Mg and Al exchangeable: extractor: $1 \mathrm{~mol} \mathrm{~L}^{-1} \mathrm{KCl}$; $\mathrm{H}+\mathrm{Al}$ : extractor $0.5 \mathrm{~mol} \mathrm{~L}^{-1}$ calcium acetate, $\mathrm{pH}$ 7.0; Organic matter (OM): Walkley-Black method; P-rem: Alvarez V. et al. (2000).

Planting was carried out in November 2003, in plant holes of $40 \times 40 \times 20 \mathrm{~cm}$. Soil samples were collected under the plant canopy in September 2008 and 2009, according to the method proposed by CFSEMG (1999). Three months before planting, soil amendment was performed by the application of $100 \mathrm{~g} / \mathrm{plant}$ of limestone (relative Total Neutralizing Power [TNP] - $98 \%$; $38 \%$ of $\mathrm{CaO}$ and $12 \%$ of $\mathrm{MgO}$ ). At planting, $200 \mathrm{~g} /$ plant of the phosphate fertilizer FH460 ${ }^{\circledR}\left(29 \%\right.$ total $\mathrm{P}_{2} \mathrm{O}_{5}$ and $14 \%$ soluble in citric acid) was applied. After the plantlets were established, three fertilizations were carried out annually, from October to March, each at the rate of $20 \mathrm{~g} / \mathrm{plant}$ of the formulation $\left(\mathrm{N}-\mathrm{P}_{2} \mathrm{O}_{5}-\mathrm{K}_{2} \mathrm{O}\right)$ 20-00-20, in 2003/ 2004 , and $42 \mathrm{~g} / \mathrm{plant}$ of the formulation $\left(\mathrm{N}-\mathrm{P}_{2} \mathrm{O}_{5}-\mathrm{K}_{2} \mathrm{O}\right)$ 24-00-12, in 2004/2005. After the beginning of the reproductive period, $280 \mathrm{~g} /$ plant of the formulation $\left(\mathrm{N}-\mathrm{P}_{2} \mathrm{O}_{5}-\mathrm{K}_{2} \mathrm{O}\right) 20-00-20+0.4 \% \mathrm{Mn}+0.4 \% \mathrm{Zn}+0.1 \%$ $\mathrm{B}$ was applied annually in three portions in the rainy period. Leaf applications of $\mathrm{Cu}, \mathrm{B}$ and $\mathrm{Zn}$ were also made, following the recommendations of CFSEMG (1999).

During the 2010/2011 crop season, leaves were sampled in the middle section of the plants in the third or fourth pairs of leaves of the plagiotropic branches when the fruits were in the initial growth stage (CFSEMG, 1999) and the N, P, K, Ca, MG, S, Zn, $\mathrm{Cu}, \mathrm{B}, \mathrm{Fe}$ and $\mathrm{Mn}$ contents were determined according to the method described by Malavolta et al. (1997).

Sources and application rates of $\mathrm{P}$ were assessed. Treatments were arranged in a full factorial design with an additional treatment $[(4 \times 3)+1]$ composed of four sources of $\mathrm{P}$ [monoammonium phosphate (48\% of $\left.\mathrm{P}_{2} \mathrm{O}_{5}\right)$, simple superphosphate $\left(18 \%\right.$ of $\left.\mathrm{P}_{2} \mathrm{O}_{5}\right)$, natural reactive rock phosphate from Algeria ( $29 \%$ of total $\mathrm{P}_{2} \mathrm{O}_{5}$ and $9 \%$ soluble in citric acid), and $\mathrm{FH} 550^{\circledR}$ (24\% of total $\mathrm{P}_{2} \mathrm{O}_{5}$ and $14 \%$ soluble in citric acid)], three application rates of $\mathrm{P}(100,200$, and 400 $\mathrm{kg} \mathrm{ha}{ }^{-1}$ year ${ }^{-1}$ of total $\mathrm{P}_{2} \mathrm{O}_{5}$ ); and an additional treatment, without application of the nutrient $\left(0 \mathrm{~kg} \mathrm{ha}^{-1}\right.$ year $^{-1}$ of total $\mathrm{P}_{2} \mathrm{O}_{5}$ ). The experimental unit was composed of three rows of 10 plants, in which the eight central plants were assessed. A randomized block experimental design was used with three replicates. The four seasons were evaluated as subplots in a split plot experiment.

The $\mathrm{P}$ application rates, for all the sources, were calculated based on the total $\mathrm{P}_{2} \mathrm{O}_{5}$ content and applied annually in October through broadcasting on the soil surface under the plant canopy, without incorporation.
The following items were assessed: yield data obtained in the 2007/2008, 2008/2009, 2009/2010 and 2010/2011 crop years; P content in the soil in 2008 and 2009; and nutrient content in the leaf tissue in reference to the 2010/2011 crop year. The biennial production cycle was assessed by calculation of the coefficients of variation of the yield data at the plot level for the four crop seasons assessed. The data were subjected to analysis of variance and regression models were fitted so as to relate the dependent variables to the application rates of $\mathrm{P}_{2} \mathrm{O}_{5}$. Models were chosen whose regression coefficients were significant up to the $5 \%$ level of probability and which exhibited the greatest adjusted coefficient of determination.

\section{RESULTS AND DISCUSSION}

There was an increase in $\mathrm{P}$ availability in the soil with the application of this nutrient through its various sources (Figure 1). The greater contents observed in the treatments with sources of lower solubility (FNR and $\mathrm{FH} 550^{\circledR}$ ) are associated with solubilization of P-Ca by the Mehlich-1 extractor (Novais \& Smyth, 1999).

Although the $\mathrm{P}$ contents in the soil used were low (mean of $6.4 \mathrm{mg} \mathrm{dm}^{-3}$ of P-Mehlich-1, with mean residual $\mathrm{P}$ of $25.7 \mathrm{mg} \mathrm{L}^{-1}$ in the $0-20 \mathrm{~cm}$ layer in the control treatment), there was no effect of the addition of this nutrient on coffee yield (Tables 2 and 3). This may be attributed to the lack of uptake of $\mathrm{P}$ by the plants as a result of surface application of the fertilizer; nevertheless, there was an increase in the leaf contents of this nutrient in response to the rates applied (Figure 2).

The leaf contents of $\mathrm{P}$, estimated by the regression equation shown in figure 2 , ranged from 1.1 to $1.48 \mathrm{~g} \mathrm{~kg}^{-1}$ of $\mathrm{P}$. These values are near or within the range considered adequate for the region of Manhuaçu (which includes the experimental area), which is 1.2 to $1.7 \mathrm{~g} \mathrm{~kg}^{-1}$ of $\mathrm{P}$ (Martinez et al., 2003). The high yields obtained may also be considered (mean yield of the four crop seasons of 64 bags/ha of hulled coffee, 2.7 times greater than the mean value of the Zona da Mata of the State of Minas Gerais), a strong indication that $\mathrm{P}$ was not a limiting factor under these conditions. 
Although some studies report an effect of phosphate fertilization applied during the production period on coffee yield (Prezotti \& Rocha, 2004; Reis et al., 2011), in general, a large increase in the yield of adult woody plants is not expected as a result of $\mathrm{P}$ supply in this phase (Novais et al., 1982), as observed in this study and in the studies of Figueiredo et al. (2006) in the south of Minas Gerais.

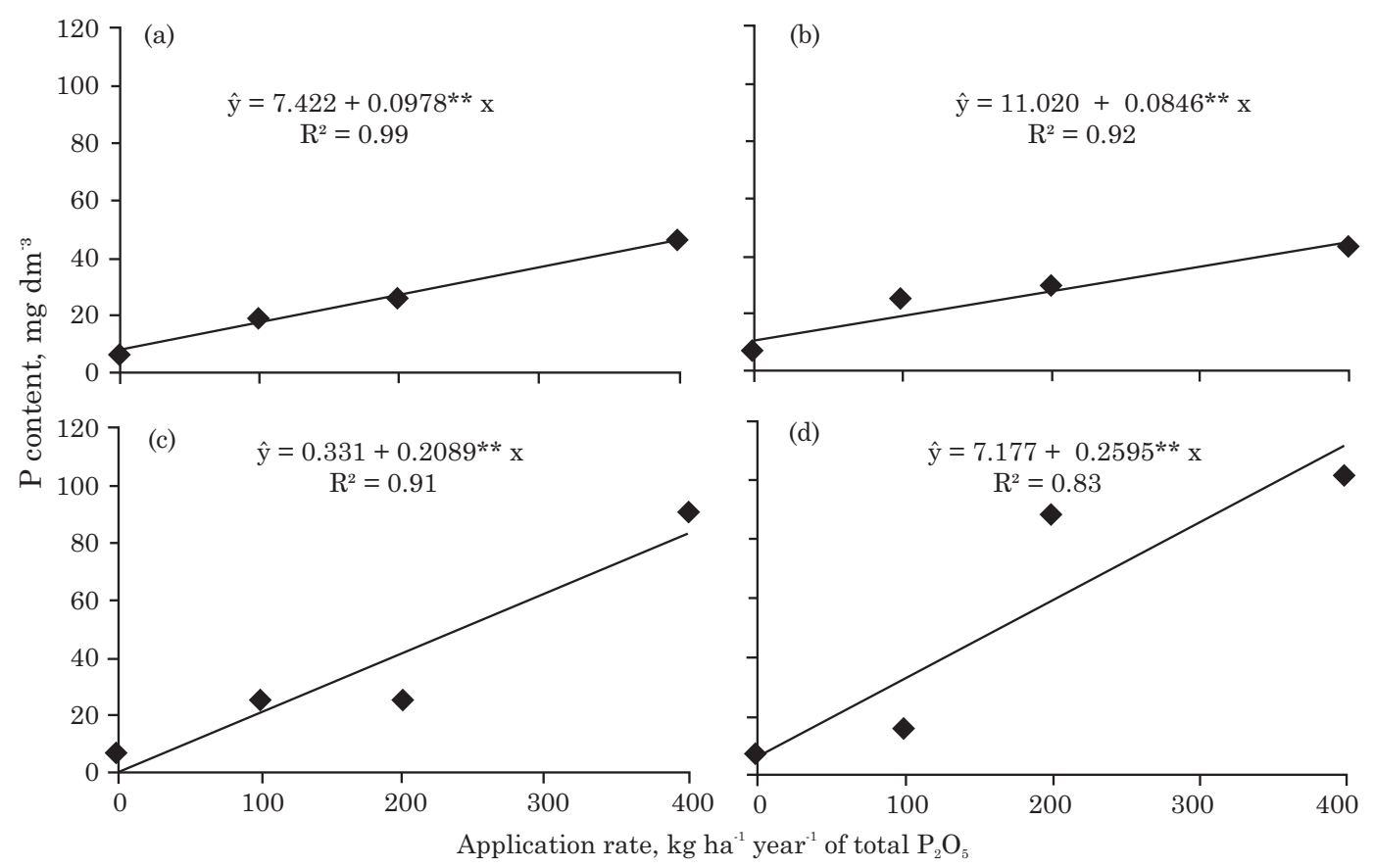

Figure 1. Content of P-Mehlich-1 in the soil, collected under the canopy of the coffee plants in September in the 0-20 cm layer in 2008 and 2009, as a function of the rates of $\mathrm{P}_{2} \mathrm{O}_{5}$ applied under the forms of simple superphosphate (a), monoammonium phosphate $(b)$, FH $550^{\circledR}(55 \%$ natural reactive rock phosphate from Algeria (Djebel-Onk) and $45 \%$ simple superphosphate) (c), and natural reactive rock phosphate from Algeria (Djebel-Onk) (d). ** significant at $1 \%$.

Table 2. Coffee yield as a function of different sources and application rates of $\mathrm{P}$ over a period of four crop seasons

\begin{tabular}{|c|c|c|c|c|c|}
\hline Crop season & Application rate & MAP $^{(1)}$ & $\mathbf{S S}^{(2)}$ & FRA $^{(3)}$ & FH550 \\
\hline & $\mathrm{g} \mathrm{ha}^{-1}$ of total $\mathrm{P}_{2} \mathrm{O}_{5}$ & & & 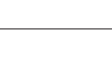 & \\
\hline \multirow[t]{4}{*}{$2007 / 2008$} & 0.0 & 77.8 & 77.8 & 77.8 & 77.8 \\
\hline & 100.0 & 88.2 & 89.1 & 83.3 & 70.6 \\
\hline & 200.0 & 75.4 & 78.3 & 77.4 & 74.6 \\
\hline & 400.0 & 70.2 & 76.4 & 82.3 & 66.1 \\
\hline \multirow[t]{4}{*}{$2008 / 2009$} & 0.0 & 74.8 & 74.8 & 74.8 & 74.8 \\
\hline & 100.0 & 57.1 & 49.4 & 80.0 & 58.6 \\
\hline & 200.0 & 84.6 & 72.3 & 73.6 & 67.5 \\
\hline & 400.0 & 80.8 & 59.7 & 64.3 & 89.5 \\
\hline \multirow[t]{4}{*}{$2009 / 2010$} & 0.0 & 23.6 & 23.6 & 23.6 & 23.6 \\
\hline & 100.0 & 35.5 & 56.0 & 23.4 & 39.6 \\
\hline & 200.0 & 25.2 & 32.4 & 15.2 & 21.6 \\
\hline & 400.0 & 17.0 & 23.4 & 25.7 & 17.0 \\
\hline \multirow[t]{4}{*}{$2010 / 2011$} & 0.0 & 73.2 & 73.2 & 73.2 & 73.2 \\
\hline & 100.0 & 71.0 & 61.2 & 83.3 & 69.4 \\
\hline & 200.0 & 73.0 & 73.0 & 75.6 & 80.8 \\
\hline & 400.0 & 62.8 & 85.9 & 78.7 & 86.4 \\
\hline
\end{tabular}

(1) Monoammonium phosphate; ${ }^{(2)}$ Simple superphosphate; ${ }^{(3)}$ Natural reactive rock phosphate from Algeria (Djebel-Onk); ${ }^{(4)}$ Mixture of $55 \%$ natural reactive rock phosphate from Algeria (Djebel-Onk) and $45 \%$ simple superphosphate. 
Table 3. Coffee yield ( $\hat{y}$, bag ha-1), as dependent variable of different sources and application rates of $\mathrm{P}\left(\mathrm{kg} \mathrm{ha}^{-1}\right.$ of $\left.\mathrm{P}_{2} \mathrm{O}_{5}\right)$ over the period of four crop seasons

\begin{tabular}{cc}
\hline Crop season & Equation/Yield \\
\hline $2007 / 2008$ & $\hat{y}=\bar{y}=77.7$ \\
$2008 / 2009$ & $\hat{y}=\bar{y}=71.0$ \\
$2009 / 2010$ & $\hat{y}=\bar{y}=26.7$ \\
$2010 / 2011$ & $\hat{y}=\bar{y}=74.6$ \\
\hline
\end{tabular}

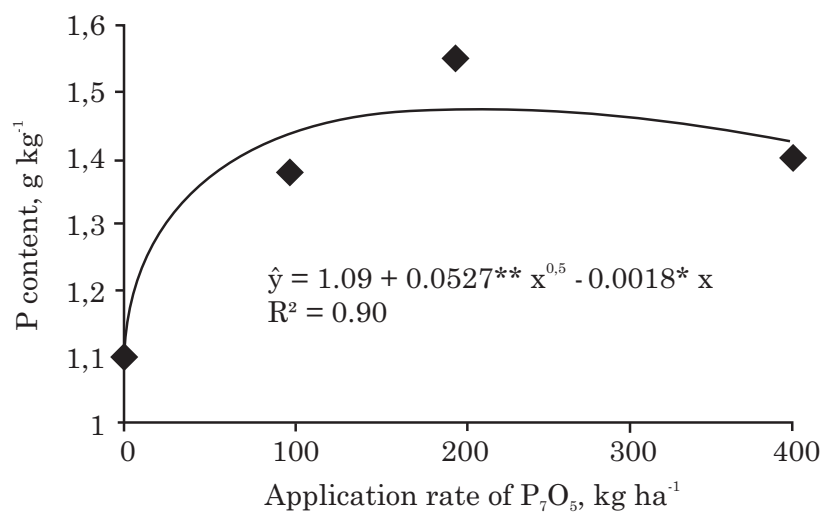

Figure 2. Mean leaf content of $P$ as a function of rates of $\mathrm{P}_{2} \mathrm{O}_{5}$ applied as a mean value for the four sources of $P$ used in the $2010 / 2011$ crop season. ** and *: significant at 1 and $5 \%$, respectively.

The nutrient, $\mathrm{P}$, is one of the macronutrients least accumulated by the coffee plant (Corrêa et al., 1986). Thus, responses of this plant to phosphate fertilization, when they occur, are due to the low availability of this nutrient in the soil, and may furthermore vary as a result of greater or lesser uptake efficiency and/ or efficiency in utilization of the nutrient by the plant, regulated by genetic and environmental factors (Novais \& Smyth, 1999; Pozza et al., 2009; Amaral et al., 2011). In spite of the complexity of these relationships, normally, critical levels of $\mathrm{P}$ decrease with the age of the plant (Novais et al., 1982). This occurs because, as the plant grows and develops, it increases its efficiency in acquiring and using nutrients, associated with an increase in the surface area of roots, with an increase of mycorrhizal associations over time, and with changes in its metabolism which, in essence, are connected with intensification of biochemical and biogeochemical cycling of the nutrient (Thinker \& Nye, 2000). In other words, the tendency is for the plant to require less $\mathrm{P}$, in relative terms, over time.

An example of how positive responses of the adult coffee plant to the addition of $\mathrm{P}$ are often due to the limited availability of the nutrient in the soil is the study of Gallo et al. (1999), carried out in two soils in the state of São Paulo. In their study, $\mathrm{P}$ addition resulted in an increase of $16 \%$ in the yield of coffee plants grown in the soil that had lower availability of the nutrient ( $13 \mathrm{mg} \mathrm{dm}^{-3}$ of $\mathrm{P}$ resin) but no response in the soil with the greater availability $\left(22 \mathrm{mg} \mathrm{dm}^{-3}\right.$ of $\mathrm{P}$ resin), in spite of both being included in the same class of $\mathrm{P}$ availability according to Raij et al. (1997).

Another example is the study of Reis et al. (2011), in which there was a great response of the adult irrigated coffee plant to the addition of P. In that study, $\mathrm{P}$ availability was very low and the soil showed high capacity for fixing this element (P-Mehlich-1 was 3.3 and $1.4 \mathrm{mg} \mathrm{dm}^{-3}$, and residual $\mathrm{P}$ was 4.5 and $4.3 \mathrm{mg} \mathrm{L}^{-1}$ in the 0-10 and 10-20 cm layers, respectively). Moreover, for comparison to this study, the effect of irrigation and the fact of the crop being in different climate conditions from those of the Zona da Mata of the State of Minas Gerais should be taken into consideration. The greater leaf contents of $\mathrm{P}$ obtained under those conditions (leaf critical level of $1.98 \mathrm{~g} \mathrm{~kg}^{-1}$ of $\mathrm{P}$ ) in relation to those obtained in this study (in which maximum leaf content was $1.48 \mathrm{~g} \mathrm{~kg}^{-1}$ of $\mathrm{P}$ ) indicate changes in $\mathrm{P}$ demand in the plants, which, among other factors, must be associated with better transport of the nutrient in the soil in which there is a supplemental water supply. That way, even a clayey soil, with low residual $\mathrm{P}$, may behave as a soil with a lower capacity factor, conditions in which the critical level of P in the plant is greater (Novais \& Smyth, 1999).

The results also generate questions in regard to the use of critical levels in the soil obtained in coffee fields with normal plant density for coffee plants in production in fields with high plant density. This hypothesis corroborates the proposition of Malavolta $\&$ Moreira (1997) that the increase in root area and greater input of organic matter in high density cropping favor $\mathrm{P}$ uptake by the crop, in detriment to its fixation in the soil. This was also shown in the study of Prezotti \& Rocha (2004), in which higher leaf contents of $\mathrm{P}$ were observed in plants grown in a high plant density system compared to those grown in a conventional system.

There was no effect of $\mathrm{P}$ application rates on the biennial cycle of coffee yield for any of the sources assessed (Figure 3). The biennial cycle was more intense between the 2009/2010 and 2010/2011 crop seasons as a function of the prolonged drought which occurred in 2010 (Table 3).

Multiple factors may alter the biennial yield cycle of coffee plants, which, basically, is associated with the lack of synchronism between their vegetative and reproductive growth (Da Matta et al., 2007). Mineral nutrition stands out in this respect (Valadares et al., 2013). A large part of the nutrients taken up by the plant are directed to the coffee fruits during the reproductive period, including $\mathrm{P}$ (Cannell, 1985). In addition, during this period, $\mathrm{P}$ uptake is reduced (Lima Filho \& Malavolta, 2003) due to lower supply of carbohydrates to the root system, which hurts the 


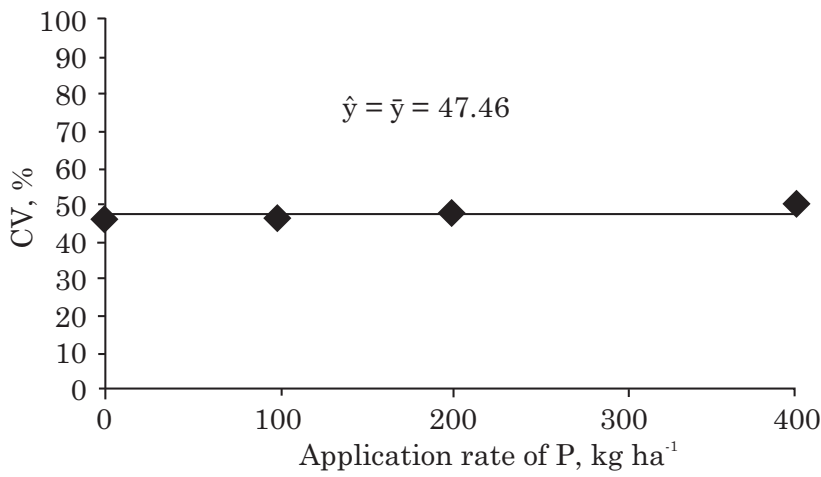

Figure 3. Mean coefficients of variation of yield in high plant density coffee as a function of rates of $\mathrm{P}_{2} \mathrm{O}_{5}$ applied for the four sources of $\mathrm{P}$ used over the period of four crop seasons.

vegetative growth of the crop and, as a consequence, the yield in the following year (Da Matta \& Rena, 2002; Rena \& Carvalho, 2003; Chaves, 2009). Using the same method of assessment of the biennial nature of yield applied in this study, under similar growing conditions, a positive effect was seen from nutrition with $\mathrm{N}$ (especially) and K on the yield stability of high plant density coffee in two field experiments (Valadares et al., 2013). The results reinforce the observation that $\mathrm{P}$ was not limiting to coffee production in this study and indicate that it is necessary to establish more adequate criteria for recommendation of this nutrient for the coffee crop and that the responses to phosphate fertilization obtained under some specific growing conditions may not be generalized.

\section{CONCLUSIONS}

1. The positive responses of coffee yield to $P$ fertilization obtained in some growing conditions may not be generalized.

2. The biennial nature of coffee production is not necessarily affected by the addition of $\mathrm{P}$.

\section{ACKNOWLEDGMENTS}

Thanks to Fertilizantes Heringer for support in developing this study and to the Coordenação de Aperfeiçoamento de Pessoal de Nível Superior (CAPES) for granting a master's degree scholarship.

\section{LITERATURE CITED}

ALVAREZ V., V.H.; NOVAIS, R.F.; DIAS, L.E. \& OLIVEIRA, J.A. Determinação e uso do fósforo remanescente. Bol. Inf. SBCS, 25:27-32, 2000.
AMARAL, J.F.T.; MARTINEZ, H.E.P.; LAVIOLA, B.G.; FERNANDES FILHO, E.I. \& CRUZ, C.D. Eficiência de utilização de nutrientes por cultivares de cafeeiro. Ci. Rural, 41:621-629, 2011.

BRAGANÇA, S.M.; SILVA, E.B.; MARTINS, A.G.; SANTOS, L.B.; LANI, J.A. \& VOLPI, P.S. Resposta do cafeeiro conilon à adubação de $\mathrm{N}, \mathrm{P}$ e $\mathrm{K}$ em sistema de plantio adensado. Coffee Sci., 4:67-75, 2009.

CANNELL, M.G. Physiology of the coffee crop. In: CLIFFORD, M.N. \& WILLSON, K.C., eds. Coffee - Botany biochemistry and production of beans and beverage. London, Crom Helm, 1985. p.108-134.

CHAVES, A.R.M. Aspectos fisiológicos do crescimento e da produção do cafeeiro. Viçosa, MG, Universidade Federal de Viçosa, 2009. 66p. (Tese de Doutorado)

COMISSÃO DE FERTILIDADE DO SOLO DO ESTADO DE MINAS GERAIS - CFSEMG. Recomendações para o uso de corretivos e fertilizantes em Minas Gerais, $5^{\text {a }}$ aproximação. Viçosa, MG, 1999. 359p.

COMPANHIA NACIONAL DE ABASTECIMENTO - CONAB. Acompanhamento da safra brasileira, terceira estimativa de 2010. Available at: <http://www.conab. gov.br/conabweb/ download/safra/2cafe_10.pdf> Accessed on: April 6, 2011.

CORRÊA, J.B.; GARCIA, A.W.R. \& COSTA, P.C. Extração de nutrientes pelos cafeeiros Mundo Novo e Catuaí. In: CONGRESSO BRASILEIRO DE PESQUISAS CAFEEIRAS, 13., São Lourenço, 1986. Anais... Rio de Janeiro, Instituto Brasileiro do Café, 1986. p.35-41.

DA MATTA, F.M. \& RENA, A.B. Ecofisiologia de cafezais sombreados e a pleno Sol. In: ZAMBOLIM, L., ed. O estado da arte de tecnologias na produção de café. Viçosa, MG, Universidade Federal de Viçosa, 2002. p.93-135.

DA MATTA, F.M.; RONCHI, C.P.; MAESTRI, M. \& BARROS, R.S. Ecophysiology of coffee growth and production. Braz. J. Plant Physiol., 19:485-510, 2007.

EMPRESA BRASILEIRA DE PESQUISA AGROPECUÁRIA EMBRAPA. Centro Nacional de Pesquisa de Solos. Sistema brasileiro de classificação de solos. 2.ed. Rio de Janeiro, 2006. 306p.

EMPRESA DE PESQUISA AGROPECUÁRIA DE MINAS GERAIS- EMATER/MG. Relatório analítico para cultura permanente: Produto - café. Belo Horizonte, 2009.

FIGUEIREDO, F.C.; FURTINI NETO, A.E.; GUIMARÃES, P.T.G.; SILVA, E.B. \& BOTREL, P.P. Eficiência da adubação com NPK na produção de cafezais adensados na região Sul de Minas Gerais. Coffee Sci., 1:135-142, 2006.

GALLO, P.B.; RAIJ, B.van.; QUAGGIO, J.A. \& PEREIRA, L.C.E. Resposta de cafezais adensados à adubação NPK. Bragantia, 58:341-351, 1999.

INSTITUTO ANTÔNIO DE SALVO - INAES. Caracterização da cafeicultura de montanha de Minas Gerais. Belo Horizonte, INAES, 2010. 300p.

LIMA FILHO, O.F. \& MALAVOLTA, E. Studies on mineral nutrition of the coffee plant (Coffea arabica L. cv. Catuai Vermelho). LXIV - Remobilization and reutilization of nitrogen and potassium by normal and deficient plants. Braz. J. Biol., 63:481-490, 2003. 
MALAVOLTA, E. \& MOREIRA, A. Nutrição, adubação do cafeeiro adensado. Inf. Agron., 80:1-8, 1997. (Encarte Técnico)

MALAVOLTA, E.; VITTI, G.C. \& OLIVEIRA, S.A. Avaliação do estado nutricional das plantas: Princípios e aplicações. 2.ed. Piracicaba, Associação Brasileira para Pesquisa do Fosfato, 1997. 238p.

MARTINEZ, H.E.P.; MENEZES, J.F.S. \& SOUZA, R.B. Critical nutrient ranges and evaluation of nutritional status in coffee-tree plantations of Minas Gerais. Pesq. Agropec. Bras., 38:703-713, 2003.

NACIF, A.P. Fenologia e produtividade do cafeeiro (Coffea arabica L.) cv. Catuaí, sob diferentes densidades de plantio e doses de fertilizante, no cerrado de Patrocínio, MG. Viçosa, MG, Universidade Federal de Viçosa, 1997. 125p. (Tese de Doutorado)

NOVAIS, R.F.; BARROS, N.F.; NEVES, J.C.L. \& COUTO, C. Níveis críticos de fósforo no solo para eucalipto. R. Árvore, 6: 29-37, 1982.

NOVAIS, R.F. \& SMYTH, T.J. Fósforo em solo e em condições tropicais. Viçosa, MG, Universidade Federal de Viçosa, 1999. $399 \mathrm{p}$.

PAVAN, M.A.; CHAVES, J.C.D. \& ANDROCIOLI FILHO, A. Produção de café em função da densidade de plantio, adubação e tratamento fitossanitário. Turrialba, 44:227$231,1994$.
POZZA, A.A.A.; CARVAlHO, J.G.; GUIMARES, P.T.G.; FIGUEIREDO, F.C. \& ARAÚJO, A. Suprimento do silicato de cálcio e a eficiência nutricional de variedades de cafeeiro. R. Bras. Ci. Solo, 33:1705-1714, 2009.

PREZOTTI, L.C. \& ROCHA, A.C. Nutrição do cafeeiro arábica em função da densidade de plantas e da fertilização com NPK. Bragantia, 63:239-251, 2004.

RAIJ, B.van; CANTARELLA, H.; QUAGGIO, J.A. \& FURLANI, A.M.C., eds. Recomendações de adubação e calagem para o Estado de São Paulo. 2.ed. Campinas, Instituto Agronômico/ Fundação/IAC, 1997. 285p. (Boletim Técnico, 100)

REIS, T.H.P.; GUIMARÃES, P.T.G.; FURTINI NETO, A.E.; GUERRA, A.F. \& CURI, N. Soil phosphorus dynamics and availability and irrigated coffee yield. R. Bras. Ci. Solo, 35:503-512, 2011.

RENA, A.B. \& CARVALHO, C.H.S. Causas abióticas da seca de ramos e morte de raízes em café. In: ZAMBOLIN, L., org. Produção integrada de café. Viçosa, MG, Universidade Federal de Viçosa, 2003. p.197-222.

THINKER, P.B. \& NYE, P.H. Solute movement in the rhizosphere. New York, Oxford University Press, 2000. 444p.

VALADARES, S.V.; NEVES, J.C.L.; ROSA, G.N.G.P.; MARTINEZ, H.E.P.; ALVAREZ V., V.H. \& LIMA, P.C. Produtividade e bienalidade da produção de cafezais adensados, sob diferentes doses de N e K. Pesq. Agropec. Bras., 48:296-303, 2013. 